3

\title{
UPGRADING OF MOIST AGRO-INDUSTRIAL WASTES BY
} HYDROTHERMAL CARBONIZATION

\author{
Verónica Benavente, Emilio Calabuig, Andres Fullana \\ Chemical Engineering Department, University of Alicante, P.O. BOX 99, E-03080 Alicante, \\ Spain \\ *Corresponding author. E-mail: veronica.benavente@ua.es. Tlf.: +(34) 965903867. Fax: \\ +(34) 965903826 .
}

\begin{abstract}
This work focuses in the application of the hydrothermal carbonization (HTC) technology as a possible moist agro-industrial waste management treatment. Through this technique, olive mill, canned artichoke and orange wastes (OMW, CAW and OJW, respectively) were carbonized in a lab-scale high pressure reactor at different temperatures $\left(200-250^{\circ} \mathrm{C}\right)$ and durations $(2,4,8$ and 24 hours) in order to obtain useful bioenergy feedstocks. The effect of the residence time and temperature on the properties of the bio-char obtained was studied through different characterization techniques. Material and energy balances were also performed to determine the potential energy saving of hydrothermal carbonization versus dry thermal treatments like torrefaction (TF). It is found that the moisture content of HTC-hydro-chars decreases as the temperature and duration increase, which implies that wet biomass can be upgraded and, at the same time, dewatered through HTC. The best results are found for the OMW, whose moisture content decreases from over $70 \%$ to less than $30 \%$ for the experiments carried out under the more severe conditions. Consequently, it is be possible to reach energy savings over $50 \%$ by using HTC instead of TF technologies. Regarding the hydro-char properties, the hydrothermal carbonization of the three organic wastes treated leaded to hydro-chars that present carbon contents and heating values closed to those of brown coal and great energy densifications, depending on the type of waste. Accordingly, it can be concluded that it is feasible to manage moist agro-industrial wastes via HTC, which is ostensibly more efficient than TF in terms of energy consumption.
\end{abstract}


Key words: hydrothermal carbonization, agro-industrial wastes, biomass, hydrochar, process conditions, energy.

\section{INTRODUCTION}

The Mediterranean region concentrates an important fraction of wine, olive oil, canned fruits and vegetables industries worldwide. Currently, part of the canning industrial wastes are intended to animal feeding, but a significant fraction ends in the landfill and increases the existing problem of lack of space. Meanwhile, fresh wine and olive mill wastes, which are high polluting by-products, are usually managed through biological treatments such as composting to produce fertilizers. However, this technology needs large processing volumes to treat the large amounts of wastes that are generated every year and, on the other hand, the digestate storage is also a problem because of the associated costs and the vast occupied space. Thus, to decrease such amounts of wastes, it would be interesting to use them as bio-energy feedstocks. Nevertheless, the combustion characteristics of agro-industrial wastes pose some technical and economic challenges and, as a consequence, the use of this kind of wastes as a bioenergy source has not been extended. Agro-industrial wastes present moisture contents that in most cases reach the $80 \%$. As a result, this kind of wastes has low calorific values and difficult and costly handling, transport and storage. Then, to make them suitable for energy production and reach all their potential as alternative energy sources, the aforementioned limitations must be overcome.

A range of pre-treatment and upgrading technologies have been developed in order to improve the biomass characteristics as bioenergy feedstocks. Among these methods, dry pyrolytic treatments such as torrefaction are being widely evaluated to produce carbonaceous solids from different biomass materials. Torrefaction (TF) is a mild pyrolysis process at temperatures between 200 and $300^{\circ} \mathrm{C}$ that converts biomass into an upgraded solid that is more suitable for international long-distance shipping for use in centralized heat and power generation [1]. Though, before conversion through dry pyrolysis, wet biomass needs to be actively dried. Therefore, moisture is a limiting factor in the thermal process efficiency due to the great deal of energy required in the pre-drying step of moist wastes. 
To avoid the costly pre-drying step, wet pyrolysis, often called hydrothermal carbonization (HTC), is mentioned as an efficient technology to carbonize moist biomass [2], [3], [4], [5], [6] and [7]. In the HTC process, biomass is heated in a high pressure reactor at temperatures lower than $350^{\circ} \mathrm{C}$. As a result, the feedstock is decomposed by a series of simultaneous reactions that occur in liquid phase, including hydrolysis, dehydratation, decarboxylation, aromatization and recondensation [7], that lowers both the oxygen and hydrogen content of the feed. The reaction products are gases, mainly carbon dioxide, carbon monoxide, hydrogen, methane, ethane and propene, and a mechanically easy to separate mixture of solid, referred to as hydro-char, and liquid, which contents the solvent used in the HTC reaction and solubilized organic products [5], [7], [8], [9], [10] and [11].

Through HTC technique, the water that is inherently in green biomass could be used as solvent to pressurize the reaction medium and then, it is not necessary to remove it from the material before to apply this method. During HTC, the phase change from water to steam is largely avoided due to the high pressures involved in the process. Then, the required energy to heat the water is smaller in comparison to that required to evaporate the same mass of water before dry pyrolytic treatments. Additionally, carbonization reactions and disruption of colloidal structures have been shown to improve the dewaterability properties of the hydro-char [12]. As a consequence, the HTC process is expected to have a great potential of energy saving versus dry thermal conversion techniques regarding to the avoided pre-drying step and the improvement in the dewatering properties of the hydro-char compared to those of the raw material.

Besides, the ash content of the biomass and its chemical composition determines its application as a bio-fuel. Biomass from agricultural products is rich in alkali metals ( $\mathrm{Na}$ and $\mathrm{K}$ ), which melt at combustion temperatures and lead to slagging and fouling deposits on the surfaces of the equipment involved in the process (furnaces, boilers) [13] and [14]. Through HTC, part of the inorganic matter of the raw biomass is found to be transferred to the liquid phase [15]. Consequently, the hydro-char ash content is expected to be lower than that of the bio-char obtained by other pyrolytic techniques, which retains the $100 \%$ of the metals contained in the raw biomass [15]. Thus, in terms of energy consumption and ash content, HTC appears as a more energy efficient disposal treatment for moist organic residues and is expected to be beneficial to improve 
102 the quality of the hydro-char as bio-energy feedstock compared to dry pyrolytic treatments.

Several research works related to the conversion of organic wastes via HTC exist in the literature, since the HTC process, first described by Bergius in 1913 [16], was rediscovered by Bobleter in the nineteen-eighties [2] and applied to organic wastes at the University of Applied Sciences Ostwestfalen-Lippe in co-operation with the MaxPlanck Intitute of Colloids and Interfaces inf Golm/Postdam (MPI) [5]. Within the last project, different organic wastes from households and industries were successfully carbonized. The produced hydro-chars were found to maintain approximately $75-80 \%$ of the carbon input. In addition, their elemental compositions and calorific values were very similar to brown coals, which make hydro-chars interesting for energy production. In the most recent literature, Lu et al. [17] found that the HTC of solid municipal waste leads to raise the departure energy density between 6.39 and 9.0 times. Xiao et al. [18] studied the HTC of cornstalk and observed that the heating value of the hydro-char was $66.8 \%$ higher than that for fresh biomass. In a similar way, Román et al. [19] treated walnut shells and sunflowers stems through HTC under different operating conditions to optimize the heating value of the hydro-char and obtained that the heating value increased from 1.5 to 1.75 fold when compared with the natural biomass. Regarding the variables studied, these authors found that temperature and water/biomass ratio were more influent on the hydrocarbonization process than residence time. Meanwhile, Oliveira et al. [6] applied the HTC process to several mixtures of agricultural wastes in order to analyze the hydro-char grade and the mass and energy losses during the treatment. They conclude that the mass and energy recoveries are increased as the waste mixtures are more lignocellulosic while the hydro-char grade improves as the waste mixtures were richer in low molecular weight carbohydrates. Pala et al. [20] compared the fuel, morphological and structural properties and the combustion characteristics of chars produced from grape pomace by both hydrothermal carbonization and torrefaction. These authors found that the char produced by torrefaction was more aromatic in nature than that obtained by HTC. However, HTC led to chars with greater energy density and combustion reactivity, which showed that HTC appears as a promising process for a winery waste having high moisture content. 
135 Studies indicate that the hydro-char properties and the performance of the products 136 depend on both the experimental conditions and the type of raw material used. Our aim 137 in this work was to upgrade moist agro-industrial wastes typical in the Mediterranean 138 region via hydrothermal carbonization to obtain profitable bio-energy feedstocks. Olive 139 mill, artichoke and orange wastes, which have not been assessed yet, were evaluated 140 because they suppose a concerning problem for the producing companies due to the 141 large volume of wastes involved. The Mediterranean area is the main producer of olive 142 oil and canned artichokes worldwide. In addition, $67 \%$ of processed artichokes resulted 143 in wastes. As a consequence, more than $10 \cdot 10^{6}$ and $7 \cdot 10^{5}$ tones are produced per year, 144 respectively. On the other hand, the production of orange juice is also important, 145 especially in Spain, and consequently more than $5 \cdot 10^{5}$ tons of orange waste are 146 produced per year. HTC experiments were carried out under different time and 147 temperature conditions to study their effect on the hydro-char properties and estimate 148 the energy saving of hydrothermal carbonization versus dry thermal treatments, such as 149 torrefaction.

150

\section{MATERIALS AND EXPERIMENTAL DESIGN}

\subsection{Materials}

154

Fresh olive mill waste (OMW) was supplied by Extremadura Agricultural and Food Technological Centre during the 2012-2013 campaign. The OMW appearance was typical of sludge. Specimens used for reactions and analyses were taken from below the surface layer of the OMW to gain a homogeneous sample, as the surface of the sludge becomes oxidized. In a similar way, fresh canned artichoke waste (CAW) and fresh orange juice waste (OJW) were collected from different artichoke canning industries and orange juice industries located in the south east of Spain. In this case, both CAW and OJW were milled in a grinder to attain homogeneity and sieved to obtain a particle size between 1 and $3 \mathrm{~mm}$. Moisture and ash content of OMW, CAW and OJW prior HTC experiments were obtained.

\subsection{HTC experimental procedure}


Two series of experiments were addressed to study the effect of residence time and temperature on the reaction products. In the first series, OMW was thermally treated at $225^{\circ} \mathrm{C}$ during residence times of $2,4,8$ and 24 hours. In the second series, OMW, CAW and OJW were processed under 200,225 and $250^{\circ} \mathrm{C}$ during 2 hours. The reaction conditions were chosen because they are known to be effective for the hydrothermal degradation of a wide range of lignocellulosic materials $\left(190-240^{\circ} \mathrm{C}\right)[5,7,21]$. The reactor pressure was not controlled in the experiments and was kept autogenic with the vapor pressure of water at the corresponding reaction temperature: $1.5 \mathrm{MPa}$ at $200{ }^{\circ} \mathrm{C}$, $25 \mathrm{MPa}$ at $225^{\circ} \mathrm{C}$ and $40 \mathrm{MPa}$ at $250{ }^{\circ} \mathrm{C}$, as indicated by the pressure gauge attached to the reactor.

The HTC experiments were conducted in a high pressure lab-scale non-stirred reactor with an internal volume of $1 \mathrm{~L}$ from Amar Equipments Pvt. Ltd. The walls of the reactor were heated by an external electrical resistance heater that was controlled using a Proportional-Integral-Derivative (PID) temperature controller. Temperatures inside and at the walls of the reactor were monitored by two $\mathrm{K}$ thermocouples. Table 1 sum up the conditions of the different experiments carried out.

Approximately, $200 \mathrm{~g}$ of moist waste was fed into the stainless steel canister of the reactor, and subsequently, this was closed and bolted shut. Note that no solvent apart from the moisture content of wastes was added for the HTC reaction. The band heater was turn on. When the reactor reached the HTC operating temperature, measurement of the residence time began. After the specified residence time period, the heater was turn off and the reactor was cooled overnight until room temperature. Afterwards, the reactor was depressurized by opening the pressure release valve and the gaseous products were collected in Tedlar bags. The solid and liquid products were removed from the canister and separated using filter paper $(5-13 \mu \mathrm{m})$. After weighing each fraction, hydro-chars were dried in an oven at $105^{\circ} \mathrm{C}$, ground into $<0.5 \mathrm{~mm}$ particles and stored in plastic sealed buckets for the subsequent characterization.

\subsection{Analytical methods}


The moisture and ash contents of OMW, CAW and OJW were obtained prior HTC experiments. The moisture content was obtained by calculating the total mass loss of samples placed in an oven model UFP500 from Memmert $\mathrm{GmbH}$ at $105^{\circ} \mathrm{C}$ until no further decrease in weight was observed (typically after 24 hours), accordingly to the European Standard EN 14774-1:2009. The ash content of the specimens was

205

206

207

208

209

210

211

212

213

214

215

216

217

218

219

220

221

222

223

224

225

226

227

228

229

230

231

232 determined by treating the samples in a Muffle serie-74 model 12-R/300 from Heron at $550^{\circ} \mathrm{C}$ during 8 hours under atmospheric conditions, accordingly to the European Standard EN 14775:2009. In addition, a Philips Analytical MagiX-PRO X-ray Fluorescence Spectrometer (XRF) was used to determine the ash composition in terms of weight fractions of the main oxide constituents.

After the experiments, the gaseous products and the hydro-char were analyzed. A low resolution mass spectrometer Agilent $5975 \mathrm{C}$ fitted with a quadrupole analyzer and coupled to a gas chromatograph Agilent7890A for capillary columns with splitless injection was used to identify the main gases generated in the HTC experiments. Regarding to the hydro-char characterization, moisture and ash contents were measured the same way than those values for the raw materials. Additionally, elemental analysis CHNS and heating value measurements of the three types of wastes and the produced hydro-chars were also carried out. The elemental analysis CHNS was conducted in an Elemental CHNS Microanalyzer Thermo Finningan Flash 1112 Series. Oxygen content was calculated by subtraction of the ash and the CHNS content from the total. Heating values were measured, accordingly to the European Standard EN 14918:2009, using a Leco AC-350 oxygen bomb calorimeter, which had an integral water-measuring and combustion vessel-filling station. Before the samples measurement, the equipment was calibrated using approximately $1 \mathrm{~g}$ of benzoic acid. Each heating value measurement was conducted at least twice. Approximately $0.7 \mathrm{~g}$ of sample was loaded into the apparatus and combusted at $25^{\circ} \mathrm{C}$ under a pressure of 450 psi of pure oxygen. Results are summarized in Table 1.

Additionally, a mass balance for each HTC experiment was performed with the data obtained in the weighing of the reaction products. The equations used for the determination of the product yields $(\%)$ were: 


$$
\text { Hydro }- \text { char Yield }(\%)=\frac{m_{\text {hydro-char }}}{m_{\text {bio }}} \cdot 100[\text { Eq. 1] }
$$

233

$$
\text { Moisture Yield (\%) }=\frac{m_{\text {evap }}}{m_{\text {bio }}} \cdot 100 \text { [Eq. 2] }
$$

234

$$
\text { Liquid Yield (\%) }=\frac{m_{\text {liquid }}}{m_{\text {bio }}} \cdot 100[\text { Eq. 3] }
$$

235

$$
\begin{aligned}
\text { Gas Yield (\%) } & =100-\text { Hydro }- \text { char Yield (\%) - Moisture Yield (\%) } \\
& - \text { Liquid Yield (\%) [Eq. 4] }
\end{aligned}
$$

236

237 where $\mathrm{m}_{\text {bio }}$ is the mass of moist waste feedstock, $\mathrm{m}_{\text {hydro-char }}$ is the mass of hydro-char 238 after filtering the mixture removed from the canister and oven drying, $\mathrm{m}_{\text {liquid }}$ is the mass 239 of the liquid phase collected after filtering the above mixture; $m_{\text {evap }}$ is the mass of water that still remains in the hydro-char after filtering.

242 Spill or droplet losses when emptying the reactor and during separation of the output 243 materials were assumed negligible. Furthermore, as the liquid phase consisted of water 244 and solubilized organic products, the hydro-char may also have retained small amounts 245 of volatile products that could have been released during its oven drying. However, for 246 calculation purposes, all mass lost registered during the oven drying of the hydro-char was assumed to be water.

249 Finally, HTC was energetically compared with TF in terms of the thermal treatments 250 applied over the water involved in both processes. Fig. 1 shows the schemes evaluated for comparison. The scheme related to the TF process also illustrates the pre-drying treatment. The scheme associated to HTC process also includes the hydro-char drying step.

The energies considered for comparison were: the energy required to evaporate the moisture content of the wastes (Energy 1); the energy required to heat the water until each experimental temperature (Energy 2), assuming that the steady state during the reaction was closed to the vapor-liquid equilibrium; and the energy required to 
259

260

261

262

263

264

265

266

267

268

269

270

271

272

273

274

275

276

277

278

279

280

281

282

283

284

285

286

287

288

289

evaporate the residual moisture of the hydro-chars after being separated from the liquid phase by filtering (Energy 3). As mechanical processes expend much less energy than heating processes, the mechanical energy invest to separate the hydro-char from the liquid phase by filtering was assumed negligible compared to the heating energy and consequently was not considered in the energy balance. In addition, neither the energy required to heat the solid during the drying steps nor the energy invested in the solid during HTC experiments were considered since the first was assumed negligible compared to that required for the evaporation of water and the second was supposed to be similar to that required during TF experiments.

Energies 1 and 3 were calculated accordingly with equation 5:

$$
\text { Energy } \mathrm{i}=\mathrm{m}_{\mathrm{i}}\left[\int_{20^{\circ} \mathrm{C}}^{100^{\circ} \mathrm{C}} \mathrm{Cp}(\mathrm{T}) \mathrm{dT}+\Delta \mathrm{H}_{\mathrm{vap}}\right] \quad \text { [eq. 5] }
$$

where $\mathrm{m}_{\mathrm{i}}$ is the mass of water in the samples $\left(\mathrm{m}_{1}\right.$ : mass of water in wastes, equal to its moisture content; $\mathrm{m}_{3}$ : mass of water in hydro-chars, equal to the product of the moisture content of the hydro-char and the moisture content of the corresponding waste), $\mathrm{Cp}(\mathrm{T})$ is the specific heat capacity of water as a function of temperature and $\Delta \mathrm{H}_{\mathrm{vap}}$ is the enthalpy of vaporization of water at $100^{\circ} \mathrm{C}$ and $101325 \mathrm{~Pa}$, which is $2257 \mathrm{~kJ} / \mathrm{kg}$. For this case of study, the calculated integral value was $318 \mathrm{~kJ} / \mathrm{kg}$.

Energy 2 was defined as indicated in Eq. 6:

$$
\text { Energy } 2=\mathrm{m}_{2}\left(\mathrm{H}_{2}-\mathrm{H}_{1}\right) \quad \text { [Eq. 6] }
$$

where $m_{2}$ is the mass of water in the initial wastes, equal to its moisture content, $H_{1}$ is the enthalpy of water at $20^{\circ} \mathrm{C}$ and $101325 \mathrm{~Pa}$, which is $84 \mathrm{~kJ} / \mathrm{kg}$, and $\mathrm{H}_{2}$ is the enthalpy of water at the operating reaction conditions.

For comparison, the energy considered in the TF process was Energy 1, which was defined as $\mathrm{E}_{\mathrm{TF}}$ (Eq.7), while the energy considered in the HTC process was defined accordingly to Eq. 8: 


$$
\mathrm{E}_{\mathrm{TF}}=\text { Energy } 1 \quad \text { [Eq. 7] }
$$

290

$$
\mathrm{E}_{\mathrm{HTC}}=\text { Energy } 2+\text { Energy } 3 \quad[\text { Eq. 8] }
$$

291

292 Additionally, the energy saving that is possible to achieve by using HTC instead of TF 293 is defined as indicated in Eq. 9:

$$
\text { Energy saving (\%) }=\frac{\mathrm{E}_{\mathrm{TF}}-\mathrm{E}_{\mathrm{HTC}}}{\mathrm{E}_{\mathrm{TF}}} \cdot 100 \quad \text { [Eq. 9] }
$$

295

\section{RESULTS AND DICUSSION}

297

\subsection{Mass balance}

299

300

The variation between the reaction products obtained was visibly notable. In the 301 experiments carried out under the softer conditions (low residence time and temperature), the product removed from the canister was a homogenous wet slush

303

304

305

306

307

308

309

310

311

312

313

314

315

316 constituted by the mixture of hydro-char and liquid phase. As the reactor residence time or temperature increased, there was a well-defined separation between the hydro-char and the liquid phase produced. After being filtered and oven dried, the hydro-chars appearance varied from a brown lignocellulosic to a black coal like material with increasing residence time or temperature.

Fig. 2 shows the reaction product yields for each experiment carried out. In the first series of experiments, it is observed that the solid yield decreases while the liquid and gas yield increase as the residence time does. In the second series, when the temperature is increased, the tendency is found to be similar to that observed with increasing residence time, and this behavior is independent of the type of waste, as all of them present the same trend. The initial lower mass yields reported are attributed to the combination of the initial feedstock solubilization and the partitioning of the feedstock to the gaseous and liquid products as a result of the reactions involved [22]. As the conditions become more severe, the rate of the initial solids disappearance increases due to the intensification of the reactions involved, and, accordingly to the results obtained by other authors [23] and [24], also probably to the dilution of aqueous extractives 
present in the solids. During HTC process, the high pressure conditions produced by the steam generated degrade hemicellulose and cellulose into water soluble monomers, which are assumed to primarily consist of sugars that could be absorbed on the remaining porous solid product [24], [25], [26] [27] and [28], thus contributing to the moist hydro-char yield. However, at higher temperatures or residence times those sugars are further degraded [25], thus, resulting in less depositionand in lower recovered mass of the solid product.

Through GC/MS, it was possible to bear out that the main gaseous products were carbon dioxide and carbon monoxide followed by methane, ethylene and hydrogen for all the experiments carried out, which represent between 35 and $40 \%$ of the total gaseous products generated in the HTC process, depending on the conditions.

Table 1 shows the moisture content of the raw wastes and the hydro-chars obtained after mechanical dewatering. It can be noted that for the OMW, the moisture content decreases from over $70 \%$ to less than $30 \%$ for the experiments carried out under the more severe conditions (longer residence time or higher temperature). With increasing residence time or temperature, it was easier to remove the hydro-char from the liquid phase. This observation may be explained as follows. For lignocellulosic biomass, moisture can be absorbed into the cell walls and hydrogen-bonded to the hydroxyl groups of the cell wall components. With the thermal treatment, the breakdown of these hydroxyl groups jointly with the hydrolysis of the hemicellulose and cellulose to monosaccharides occur and these reactions become increasingly significant with an increase in temperature and/or residence time. As a consequence, the solid becomes more hydrophobic under the more severe conditions. Thereby, the reduction in hydrophilic nature of the solid allowes physical dewatering to occur easier and, as a result, the moisture of the hydro-chars decreases.

The reduced moisture content and the improved hydrophobic properties are advantageous in the storage of the hydro-chars. These solids could be stored stably over time, with low risk of biological deterioration, to accommodate seasonal availability. Also, its transportation would be less expensive, because there would be less moisture to transport along with the biomass. 
354 For CAW and OJW derived hydro-chars, the moisture content drop is less pronounced,

355 what suggests that their hydrophobicity is not as improved as that of the OMW derived

356

357

358

359

360

361

362

363

364

365

366

367

368

369

370

371

372

373

374

375

376

377

378

379

380

381

382

383

384

385

386

387 hydro-chars. For the CAW, the moisture content decreases from $86 \%$ to $84 \%$ for the hydro-chars obtained at 200 and $225^{\circ} \mathrm{C}$ and to $79 \%$ for the sample obtained at $250^{\circ} \mathrm{C}$. For the OJW, the moisture content only decreases from almost $79 \%$ to about $76 \%$ for the hydro-chars obtained at 200 and $225^{\circ} \mathrm{C}$ and $71 \%$ for the sample obtained at $250^{\circ} \mathrm{C}$. These results agree with those observed by Oliveira et al. [6], who found that, depending on the input material, the decrease in the moisture content after mechanical dewatering could be completely different. Then, hydrothermal carbonization improves the dewatering properties of materials with high moisture content but, in addition of residence time and temperature, the hydro-chars moist degree also depends on the type of waste carbonized.

3.2. Characterization of the hydro-chars (CHNOS analysis, heating value and ash content and composition)

Table 1 shows the elemental composition of the raw materials and the hydro-chars obtained after mechanical dewatering and oven drying. By comparing the elemental composition of input and output materials, it is possible to realize about the intensity of the carbonizations process. The more severe were the reaction conditions, the higher the carbon content that remained in the solid phase. For the three wastes studied, it can be observed that the $\mathrm{H}$ content keeps almost constant, while the oxygen content is decreased as the residence time or temperature rise and, consequently, the carbon content increases from $56 \%$ to $73 \%$ for the OMW derived hydro-chars, from $43 \%$ to $66 \%$ for the CAW derived hydro-chars and from $45 \%$ to $68 \%$ for the OJW derived hydro-chars. From these data, the carbon percentage retained in the solid products was calculated and these values are indicated in Table 1. It is shown that the hydro-chars obtained from OMW and CAW retained between $70 \%$ and $50 \%$ of the C content in the initial wastes, which decreases as the severity of the reactions increases. Regarding to those obtained from OJW, it is found that these hydro-chars present higher percentages of carbon retained in the solid product, which range from $93 \%$ for the softest conditions to $77 \%$ for the most aggressive environment. By comparing the effect of residence time and temperature, it is seen that the elemental composition of the hydro-char obtained from OMW at the longest residence time is similar to that of the hydro-char obtained 
from OMW at the highest temperature. Then, high temperatures compensate the long

389

390

391

392

393

394

395

396

397

398

399

400

401

402

403

404

405

406

407

408

409

410

411

412

413

414

415

416

417

418

419

420

421 residence time needed at lower temperatures, since the elemental composition of the hydro-char prepared at $250^{\circ} \mathrm{C}$ during $2 \mathrm{~h}$ matches the hydro-char prepared at $200^{\circ} \mathrm{C}$ during $24 \mathrm{~h}$. The sulfur content is significantly low for all the samples analyzed, as it is under the detection limit of the elemental microanalyzer used in all cases. The $\mathrm{N}$ content increases with longer residence times and higher temperatures, although this tendency is not clear for the hydro-chars obtained from CAW and OJW.

From the elemental analysis data, $\mathrm{H} / \mathrm{C}$ and $\mathrm{O} / \mathrm{C}$ molar ratios were calculated. The results are plotted in the Van Krevelen diagram to illustrate the hydrothermal carbonization process (Fig. 3). It is observed that as the severity of the HTC process increases, both $\mathrm{H} / \mathrm{C}$ and $\mathrm{O} / \mathrm{C}$ ratios linearly move from upper right to lower left, which indicates that dehydratation and decarboxylation reactions occur during the carbonization, resulting in hydro-chars with more aromatic structures and, consequently, more hydrophobic than the input materials [8]. Nevertheless, the evolution essentially follows the path of a dehydration process, what suggests that significant decarboxylation only appears after plenty of water has been generated [9]. On the other hand, these reactions are more intense as the severity conditions are intensified, accordingly to the greater length of the vector, which starts at the input analysis and ends at the output analysis [4] and [5].

It is worth mentioning that the carbonization of the OMW is slightly different from the other wastes possibly due to the high organic matter content [29] and [30] and the olive oil that still remains in the olive mill residue, which is mainly constituted by oleic acid. This content in organic matter contributes to increase the molar ratio $\mathrm{H} / \mathrm{C}$ and as a consequence, the carbonization pathway is over those that CAW and OJW describe, although the pathway direction is the same in all cases. At $200^{\circ} \mathrm{C}$, it seems that the organic matter present in the input material remains in the hydro-char obtained. However, at $225^{\circ} \mathrm{C}$, there is a significant drop in the $\mathrm{H} / \mathrm{C}$ molar ratio, which suggests that from this temperature the organic matter is partly removed from the hydro-char, either because they are thermally degraded or transferred to the liquid phase.

The quality of the carbonaceous solids produced by hydrothermal carbonization could be compared to that of bituminous reach brown coal, lignite or even sub-bituminous coal, depending on the reaction severity and the type of organic waste used. Fig. 3 
422 shows that the organic wastes go towards those forms of brown coal via interim steps

423 peat and lignite. Only the hydro-chars produced from OJW nearly reach the region of 424 lignite coal, which is high quality lignite. In the case of CAW, the hydro-chars obtained 425 at 200 and $225^{\circ} \mathrm{C}$ are typically lignite brown coal, while the one obtained at $250^{\circ} \mathrm{C}$ 426 reaches the region of bitumen rich brown coal due to the higher H/C molar ratio. 427 Likewise, the hydro-chars obtained from OMW are also typical bitumen-rich brown 428 coal due to the major content of $\mathrm{H}$ associated to the olive oil that still remains in the 429 hydro-char after the thermal treatment. Therefore, the coalification degree is relevant to 430 both the HTC conditions and the material used, which agree the results found by other 431 authors [5], [6], [31] and [32].

432

433 The energy density of the raw organic wastes is improved due to the decrease in the number of low energy $\mathrm{H} / \mathrm{C}$ and $\mathrm{O} / \mathrm{C}$ bonds and the increase of high energy $\mathrm{C}-\mathrm{C}$ bonds [31]. Fig. 4 shows the evolution of the low heating value for the two series of experiments carried out. It is observed that the heating value of the hydro-chars produced from OMW is enhanced with the increasing residence time. Similar trends are observed when the type of waste and the effect of time are discussed since the low heating value is improved as the reaction temperature increases, independently of the type of waste. However, as expected from the $\mathrm{H} / \mathrm{C}$ and $\mathrm{O} / \mathrm{C}$ molar ratios, this improvement is higher for CAW and OJW. In these cases, the best values almost 442 duplicate the calorific value of the raw wastes. Table 1 indicates the energy 443 densification ratio. In all tests, a significant increase in energy density can be confirmed. 444 It is seen that the residence time and temperature have the same effect over this 445 parameter. In addition, the maximum energy densification ratios are found for the 446 hydro-chars produced from CAW, followed by those produced from OJW and OMW. 447 Thus, for the CAW derived hydro-char prepared under the more sever reaction 448 conditions, the energy densification ratio is 1.87 , while for the OJW and OMW derived 449 hydro-chars these values drop until 1.73 and 1.26 (highest temperature) or 1.23 (longest residence time), respectively.

Fig. 5 illustrates the hydro-chars low heating value and carbon content. It is shown that there is a significant correlation between the carbon content and the heating value of the materials tested, as expected from the literature [5]. The resulting vector connecting input to output material is directed from lower left to upper right and displays the 
increasing carbon content and heating value as the environmental conditions of the reaction become more severe. The carbon content and the low heating values obtained are typical of brown coal [5]. Therefore, the hydrochars derived from OMW, CAW and OJW might be of interest for energy production and they could partly replace the mineral brown in power energy generation plants.

Another important property of a fuel material is the ash content and its composition, since alkaline metals, such as $\mathrm{K}$, are involved in reactions that lead to slagging and fouling deposits on the combustor heat transfer surfaces [33] and [34], $\mathrm{S}$ and $\mathrm{Cl}$ are known to promote corrosion problems on the combustion facilities [35], and $\mathrm{Cl}$ can also serve as a source for chlorinated dioxin formation in a furnace, increasing the risk to emit toxic dioxins and furans [35] and [36]. Biomass ashes are rich in such elements. Then, in order to decrease its slagging, fouling, corrosion and Cl-dioxin formation potential, it is imperative to decrease the content of these elements in the final bioenergy product.

Table 1 indicates the ash content of the hydro-chars produced in each HTC experiment. For the experiments carried out with OMW at $225^{\circ} \mathrm{C}$ during different residence times it is noted that all the samples have similar ash contents, but these are much lower than the initial ash content of the OMW, due to the transfer of metals to the liquid phase during the HTC reaction. With increasing temperature, the trends observed are different depending on the type of waste. The ash content of the hydro-chars produces from OMW decreases as the temperature rises. However, the values obtained for the hydrochars produced from CAW and OJW are kept almost constant or even slightly increased, what suggests that the metals that remain in the solid phase could have led to insoluble compounds during the HTC reaction, resulting in higher ash contents.

Table 2 shows the ash composition obtained through X-ray fluorescence (XRF) analysis and the high heating value of the respective hydro-char. Accordingly to these values, the alkali index of each sample was calculated accordingly to Eq. 10, where Q is the high heating value of the fuel, $\mathrm{Y}_{\mathrm{f}}^{\mathrm{a}}$ is the mass fraction of ash in the fuel and $\mathrm{Y}_{\mathrm{K} 2 \mathrm{O}}{ }^{\mathrm{a}}$ and $\mathrm{Y}_{\mathrm{Na} 2 \mathrm{O}}{ }^{\mathrm{a}}$ are the mass fractions of $\mathrm{K}_{2} \mathrm{O}$ and $\mathrm{Na}_{2} \mathrm{O}$ in the ash [34]. 


$$
\text { Alkali Index }=\frac{\mathrm{Y}_{\mathrm{f}}^{\mathrm{a}}\left(\mathrm{Y}_{\mathrm{K}_{2} \mathrm{O}}^{\mathrm{a}}+\mathrm{Y}_{\mathrm{Na}_{2} \mathrm{O}}^{\mathrm{a}}\right)}{\mathrm{Q}}
$$

489

490

491

492

493

494

495

496

497

498

499

500

501

502

503

504

505

506

507

508

509

510

511

512

513

514

515

516

517

518

519

520

The alkali index is one of the most significant threshold indicator for fouling and slagging and expresses the quantity of alkali oxide in the fuel per unit of fuel energy $(\mathrm{kg}$ alkali. $\mathrm{GJ}^{-1}$ ). Above $0.17 \mathrm{~kg}$ alkali $\mathrm{GJ}^{-1}$ fouling is probable and above $0.34 \mathrm{~kg} \mathrm{GJ}^{-1}$ fouling is theoretically certain to occur [34].

The alkali index is found to be $0.66,1.09$ and $0.52 \mathrm{~kg}$ alkali. $\mathrm{GJ}^{-1}$, for OMW, CAW and OJW, respectively. These values are typical from herbaceous and fruit biomass and imply that fouling per alkali metals during combustion of these agro-industrial wastes would theoretically occur. Nevertheless, the alkali index decreases when the wastes are treated by hydro-thermal carbonization as a consequence of the lower $\mathrm{K}_{2} \mathrm{O}$ content, what suggests that the slagging and fouling potential of the hydro-chars is lower than that of the unreacted wastes. The best results are found for the OMW derived hydrochars, whose values are under $0.17 \mathrm{~kg}$ alkali $\mathrm{GJ}^{-1}$ and closed to the alkali index of coal (approximately $0.03 \mathrm{~kg}$ alkali $\mathrm{GJ}^{-1}$ ) [34] when the more severe conditions are applied during the HTC process. In this sense, the possible slagging and fouling problems associated to the OMW combustion are improved via HTC. On the other hand, the alkali index drop obtained for the CAW and OJW derived hydro-chars is less pronounce and only the hydro-chars obtained from OJW present values under $0.34 \mathrm{~kg} \mathrm{GJ}^{-1}$, what suggests that for these kind of wastes slagging and fouling are more likely to occur.

Furthermore, oxides and $\mathrm{Cl}$ mass balances were carried out. Fig. 6 shows the percentage of the main oxides detected in the dry hydro-chars prepared. The amount of $\mathrm{Si}, \mathrm{Mg}, \mathrm{P}$, $\mathrm{Fe}$ and $\mathrm{S}$ oxides recovered in the hydro-chars increases with increasing residence time (Fig. 6a), what suggests that, although part of this compounds are transferred to the liquid phase, those remaining in the carbonaceous solid lead to insoluble compounds and contribute to higher oxide yields. Otherwise, most of the $\mathrm{Cl}$ is removed from the solid and shift to the liquid phase as the residence time increases. Similar trends are observed for the OMW derived hydro-char with increasing temperature (Fig. 6b), with the exception of $\mathrm{Fe}_{2} \mathrm{O}_{3}$ and $\mathrm{SO}_{3}$, which in this case decrease. Regarding to Fig. 6c and Fig. 6d, it is observed that the trends also depend on the type of waste. The percentage of $\mathrm{K}_{2} \mathrm{O}, \mathrm{MgO}, \mathrm{SO}_{3}$ and $\mathrm{Cl}$ recovered in the hydro-chars produced from CAW decreases 
521 with increasing temperature, while the $\mathrm{MgO}$ and $\mathrm{SO}_{3}$ yields in the hydro-chars produced

522 from $\mathrm{OJW}$ increase. The $\mathrm{MgO}$ recovery is $100 \%$. On the other hand, $\mathrm{K}_{2} \mathrm{O}$ and $\mathrm{Cl}$ do not

523

524

525

526

527

528

529

530

531

532

533

534

535

536

537

538

539

540

541

542

543

544

545

546

547

548

549

550

551

552

553

554 show a clear trend with increasing temperature.

\subsection{Energy considerations}

Table 3 shows the results obtained in the energy balance. The dying step needed before torrefaction requires $1821 \mathrm{MJ} / \mathrm{kg}$ OMW, $2213 \mathrm{MJ} / \mathrm{kg}$ OMW and $2045 \mathrm{MJ} / \mathrm{kg}$ OMW to entirely evaporate the water in each type of waste. However, if we treat these wastes via HTC, the energy consumption decrease until the values indicated in Table 3 depending on the operating conditions and the type of waste. The lower the moisture content of the hydro-char mechanically dewatered, the lower the total energy invested in the HTC process. Then, the moisture of the hydro-char obtained after mechanical dewatering is a key factor in the energy efficiency of the HTC process.

It is possible to achieve excellent energy savings by using HTC instead of TF, which are over $50 \%$ and $40 \%$ when the highest experimental temperature is applied to OMW and CAW, respectively. However, as the hydro-char moisture content drop is less pronounced $\mathrm{E}_{\mathrm{HTC}}$ increases and, consequently, the energy savings are lower. Thus, in the case of OJW, the energy saving for the highest temperature is lower than $30 \%$, which is not as good as for the other wastes. These results could have been improved if a filter press had been used for the mechanical dewatering of the hydro-chars. Even though, HTC process appears as a more energetically efficient process than TF process for the agro-industrial wastes studied.

Table 3 also shows the same analysis for OMW with increasing residence time at $225^{\circ} \mathrm{C}$. It is seen that the energy saving is increased as the residence time is longer due to the reduction in the hydro-char moisture content. However, the effect of time in the hydro-char moisture content is less important than that of temperature, and this is traduced into a minor effect on the energy savings calculated. The energy saving found for the $24 \mathrm{~h}$ experiment is closed to that of the experiment carried out at $250^{\circ} \mathrm{C}$ during 2 h. In addition, the energy to maintain the HTC reaction during longer residence times would be also higher. Then, no significant holding time over $2 \mathrm{~h}$ is needed to achieve better results. 


\section{CONCLUSIONS}

557

558 Accordingly to the results obtained, it is concluded that the organic wastes produced in

559 olive mill, canned artichoke and orange juice industries could be transform into

560 profitable bioenergy feedstocks similar to brown coal by employing the hydrothermal

561 carbonization technology. The HTC process allows upgrading and dewatering these

562 substrates, which initially had moisture contents over $70 \%$. The carbon content, heating

563 value, ash content and composition and the dewatering properties are improved by

564 increasing the residence time and the reaction temperature. Additionally, these

565 properties are also found to be affected by the type of organic waste carbonized. The

566 dewatering properties are more improved for the OMW derived hydro-chars, and

567 consequently, it was possible to achieve better energy savings when comparing the HTC

568 process of OMW with the torrefaction.

569

\section{ACKNOWLEDGEMENTS}

571

572 Authors kindly wish to thank the Spanish Ministry of Economy and Competitiveness

573 and the Spanish Ministry for Education and Science for financial support (INNPACTO

574 Project IPT-2012-0565-310000 and contract grant number 8850828). The author V.

575 Benavente also thanks the Conselleria d'Educación, Cultura i Esport, for a Ph.D. grant

576 (contract grant number ACIF/2014/275).

577

578 REFERENCES

579

580

581

582

583

584

585

586

[1] D. Ciolkosz, R. Wallace, A review of torrefaction for bioenergy feedstock production, Biofuel Bioprod. Biorefining, 5 (2011), 317-29.

[2] O. Bobleter, H. Binder, R. Concin, E. Burtscher, The conversion of biomass to fuel raw material by hydrothermal treatment, Appl. Sci. Publ., Energy from Biomass (1981), 554-562.

[3] M.J. Antal, Jr., E. Croiset, X. Dai, C. DeAlmeida, W. Shu-Lai Mok, N. Norberg, High-Yield Biomass Charcoal, Energ. Fuel., 10 (1996), 652-658.

[4] F. Behrendt, Direktverflüssigung von Biomasse-Reaktionsmechanismen und Produktverteilungen, Institut für Energietechnik, Technische Universität Berlin 

Projektnummer 114-50-10-0337/05-B.

[5] H.G. Ramke, D. Blöse, H.J. Lehmann, J. Fetting, Hudrothermal carbonization of organic wastes, in: Cossu, R., Diaz, L.F., Stegmann, R. (Eds.). Sardinia 2009: Twelfth International Waste Management and Landfill Symposium Proceedings, CISA Publisher (ISBN 978-88-6265-007-6).

[6] I. Oliveira, D. Blöse, H.G. Ramke, Hydrothermal carbonization of agricultural residues, Bioresource Technol., 142 (2013), 138-146.

[7] J.A. Libra, K.S. Ro, C. Kammann, A. Funke, N.D. Berge, Y. Neubauer, M.M. Titirici, C. Fühner, O. Bens, J. Kern, K.H. Emmerich, Hydrothermal carbonization of biomass residuals: a comparative review of the chemistry, processes and applications of wet and dry pyrolysis, Biofuels, 2(1) (2011), 89124.

[8] N.D. Berge, K.S. Ro, J. Mao, J.R.V. Flora, M.A. Chappell, S. Bae, Hydrothermal carbonization of municipal waste streams, Environ. Sci. Technol., 45 (2011), 5696-5703.

[9] A. Funke, F. Ziegler, Hydrothermal carbonization of biomass: A summary and discussion of chemical mechanisms for process engineering, Biofuels, Bioprod. Biorefin., 4 (2010), 160-177.

[10] I.H. Hwang, K. Kawamoto, Survey of carbonization facilities for municipal solid waste treatment in Japan, Waste Manage., 30 (2010), 1423-1429.

[11] I.H. Hwang, H. Aoyama, T. Matsuto, T. Nakagishi, T. Matsuo. Recovery of solid fuel from municipal solid waste by hydrothermal treatment using subcritical water, Waste Manage., 32 (2012), 410-416.

[12] A.T. Mursito, T. Hirajima, K. Sasaki, Upgrading and dewatering of raw tropical peat by hydrothermal treatment, Fuel, 89(3) (2010), 635-641.

[13] A. Khan, W. De Jong, P. Jansens, H. Spliethoff, Biomass combustion in fluidized bed boilers: potential problems and remedies, Fuel Process. Technol., 90 (2009), 21-50.

[14] R. Saidur, E. Abdelaziz, A. Demirbas, M. Hossain, S. Mekhilef, A review on biomass as a fuel for boilers, Renew. Sust. Energy Rev., 15 (2011), 2262-2289.

[15] Z. Liu, A. Quek, S.K. Hoekman, R. Balasubramanian, Production of solid biochar fuel from waste biomass by hydrothermal carbonization, Fuel, 103 (2013), 943949.

[16] F. Bergius, Nobel Lecture: Chemical Reactions under High Pressure". Nobelprize.org. Nobel Media AB 2014. Web. 18 Jul 2014. 
http://www.nobelprize.org/nobel_prizes/chemistry/laureates/1931/bergiuslecture.html.

[17] X. Lu, B. Jordan, N.D. Berge, Thermal conversion of municipal solid waste via hydrothermal carbonization: Comparison of carbonization products to products from current waste management techniques, Waste Manage., 32 (2012), 13531365 .

[18] L.P. Xiao, Z.J. Shi, F. Xu, R.C. Sun, Hydrothermal carbonization of lignocellulosic biomass, Bioresource Technol., 118 (2012), 619-623.

[19] S. Román, J.M.V. Nabais, C. Laginhas, B. Ledesma, J.F. González, Hydrothermal carbonization as an effective way of densifying the energy content of biomass, Fuel Process. Technol., 103 (2012), 78-83.

[20] M. Pala, I.C. Kantarli, H.B. Buyukisik, J. Yanik, Hydrothermal carbonization and torrefaction of grape pomace: a comparative evaluation, Bioresource Technol., 161 (2014), 255-262.

[21] Bobleter, O. Hydrothermal Ddgradation of polymers derived from plants, Prog. Polym. Sci., 19 (1994), 797-841.

[22] X. Lu, P.J. Pellechia, J.R.V. Flora, N.D. Berge, Influence of reaction time and temperature on product formation and characteristics associated with the hydrothermal carbonization of cellulose, Bioresource Technol., 138 (2013), 180190.

[23] M.T. Reza, W. Yan, M.H. Uddin, J.G. Lynam, S.K. Hoekman, C.J. Coronella, V.R. Vásquez, Reaction kinetics of hydrothermal carbonization of loblolly pine, Bioresource Technol., 139 (2013), 161-169.

[24] W. Yan, T.C. Acharjee, C.J. Coronella, Víctor R. Vásquez, Thermal Pretreatment of Lignocellulosic Biomass, Environ. Prog. Sustain. Energy., 28(3) (2009), 435440.

[25] S.K. Hoekman, A. Broch, C. Robbins, Hydrothermal carbonization (HTC) of lignocellulosic biomass, Energ. Fuel., 25 (2011), 1802-1810.

[26] M.J. Antal, Jr., W.S.L. Mok, G.N. Richards, Mechanism of formation of 5(Hydroxymethyl)-2-Furaldehyde from d-glucose and sucrose. Carmohydr. Res., 199 (1990), 91-109.

[27] M. Keiluweit, P.S. Nico, M.G. Johnson, M. Kleber, Dunamic Molecular Structure of Plant Biomass-Derived Black Carbon (biochar), Environ. Sci. Technol., 44 (2010), 1247-1253.

[28] W. Yan, J.T. Hastings, T.C. Acharjee, C.J. Coronella, V.R. Vásquez, Mass and energy balances of wet torrefaction of lignocellulosic biomass, Energ. Fuel., 24 (2010), 4738-4742. 
[29] J.A. Alburquerque, J. Gonzálvez, D. García, J. Cegarra, Agrochemical characterization of "alperujo", a solid by-product of two-phase centrifugation method for olive oil extraction, Bioresour. Technol., 91 (2004), 195-200.

[30] A. Roig, M.L. Cayuela, M.A. Sánchez-Monedero, An overview on olive mill wastes and their valorization methods, Waste Manage., 26 (2006), 960-969.

[31] P. Zhao, Y. Shen, S. Ge, Z. Chen, K. Yoshikawa, Clean solid biofuel production from high moisture content waste biomass employing hydrothermal treatment, Appl. Energ., 131 (2014), 345-367.

[32] X. Cao, K.S. Ro, J.A. Libra, C.I. Kammann, I. Lima, N. Berge, L. Li, Y. Li, N. Chen, J. Yang, B. Deng, J. Mao, Effects of biomass types and carbonization conditions on the chemical characteristics of hydrochars, J. Agric. Food Chem., 61 (2013), 9401-9411.

[33] J. Kalembkiewicz, U. Chmielarz, Ashes from co-combustion of coal and biomass: New industrial wastes, Resour. Conserv. Recy., 69 (2012), 109-121.

[34] B.M. Jenkins, L.L. Baxter, T.R. Miles Jr., T.R. Miles, Combustion properties of biomass, Fuel Process. Tech., 54 (1998), 17-46.

[35] I. Obernberger, T. Brunner, G. Barnthaler, Chemical properties of solid biofuels significance and impact, Biomass Bioenerg., 30 (2006), 973-82.

[36] G. McKay, Dioxin characterization, formation and minimization during municipal solid waste (MSW) incineration: review, Chem. Eng. J., 86 (2002), 343-68. 
Tables

Table 1. Ultimate analysis (wt.\% dry basis), moisture content (wt.\%), ash content (wt.\% dry basis), C-content retained in the solid phase (\%) and energy densification ratio.

\begin{tabular}{|c|c|c|c|c|c|c|c|c|c|}
\hline \multirow{2}{*}{ Sample Id. } & \multicolumn{3}{|c|}{ Ultimate Analysis (wt.\% d.b.) } & $\begin{array}{c}\text { Moisture } \\
\text { content } \\
\text { (wt.\%) }\end{array}$ & $\begin{array}{c}\text { Ash } \\
\text { content } \\
\text { (wt.\% d.b.) }\end{array}$ & $\begin{array}{c}\text { C-solid } \\
(\%)\end{array}$ & $\begin{array}{c}\text { Energy } \\
\text { densification } \\
\text { ratio }\end{array}$ \\
\hline OMW & 56.11 & 7.39 & $<0.1$ & 0.75 & 30.24 & 70.71 & 5.51 & 100 & - \\
\hline CAW & 43.17 & 5.96 & $<0.1$ & 2.95 & 41.46 & 85.95 & 6.46 & 100 & - \\
\hline OJW & 45.37 & 6.20 & $<0.1$ & 1.34 & 43.75 & 79.41 & 3.34 & 100 & - \\
\hline $\begin{array}{c}\text { OMW } \\
\left(225^{\circ} \mathrm{C}, 2 \mathrm{~h}\right)\end{array}$ & 66.05 & 7.96 & $<0.1$ & 1.43 & 22.30 & 55.10 & 2.26 & 70 & 1.12 \\
\hline $\begin{array}{c}\text { OMW } \\
\left(225^{\circ} \mathrm{C}, 4 \mathrm{~h}\right)\end{array}$ & 68.24 & 8.18 & $<0.1$ & 1.47 & 19.92 & 52.16 & 2.19 & 69 & 1.18 \\
\hline $\begin{array}{c}\text { OMW } \\
\left(225^{\circ} \mathrm{C}, 8 \mathrm{~h}\right)\end{array}$ & 70.10 & 7.97 & $<0.1$ & 1.60 & 18.26 & 45.10 & 2.07 & 67 & 1.20 \\
\hline $\begin{array}{c}\text { OMW } \\
\left(225^{\circ} \mathrm{C},\right. \\
24 \mathrm{~h})\end{array}$ & 73.01 & 8.33 & $<0.1$ & 1.72 & 14.76 & 29.63 & 2.17 & 61 & 1.26 \\
\hline $\begin{array}{c}\text { OMW } \\
\left(200^{\circ} \mathrm{C}, 2 \mathrm{~h}\right)\end{array}$ & 63.25 & 8.20 & $<0.1$ & 1.12 & 24.08 & 59.51 & 3.35 & 70 & 1.03 \\
\hline $\begin{array}{c}\text { OMW } \\
\left(250^{\circ} \mathrm{C}, 2 \mathrm{~h}\right)\end{array}$ & 71.85 & 8.27 & $<0.1$ & 1.66 & 16.27 & 27.13 & 1.95 & 58 & 1.23 \\
\hline $\begin{array}{c}\mathrm{CAW} \\
\left(200^{\circ} \mathrm{C}, 2 \mathrm{~h}\right)\end{array}$ & 55.52 & 5.77 & $<0.1$ & 3.52 & 28.14 & 83.67 & 7.06 & 71 & 1.54 \\
\hline $\begin{array}{c}\mathrm{CAW} \\
\left(225^{\circ} \mathrm{C}, 2 \mathrm{~h}\right)\end{array}$ & 55.96 & 5.70 & $<0.1$ & 3.31 & 27.79 & 83.76 & 6.96 & 65 & 1.61 \\
\hline $\begin{array}{c}\mathrm{CAW} \\
\left(250^{\circ} \mathrm{C}, 2 \mathrm{~h}\right)\end{array}$ & 66.24 & 5.75 & $<0.1$ & 4.52 & 16.15 & 78.77 & 7.35 & 50 & 1.87 \\
\hline $\begin{array}{c}\mathrm{OJW} \\
\left(200^{\circ} \mathrm{C}, 2 \mathrm{~h}\right)\end{array}$ & 62.93 & 5.49 & $<0.1$ & 1.26 & 26.32 & 76.68 & 4.01 & 93 & 1.48 \\
\hline $\begin{array}{c}\text { OJW } \\
\left(225^{\circ} \mathrm{C}, 2 \mathrm{~h}\right)\end{array}$ & 64.92 & 5.40 & $<0.1$ & 1.25 & 23.98 & 76.44 & 4.45 & 89 & 1.58 \\
\hline $\begin{array}{c}\text { OJW } \\
\left(250^{\circ} \mathrm{C}, 2 \mathrm{~h}\right)\end{array}$ & 68.19 & 5.36 & $<0.1$ & 1.35 & 21.05 & 70.60 & 4.05 & 77 & 1.73 \\
\hline
\end{tabular}


Table 2. Ash composition (w.t.\%) and alkali index of the hydro-chars produced.

\begin{tabular}{|c|c|c|c|c|c|c|c|c|c|c|c|}
\hline \multirow{2}{*}{ Sample } & \multicolumn{9}{|c|}{$\%$} & \multirow{2}{*}{$\begin{array}{c}\mathrm{HHV} \\
(\mathrm{MJ} / \mathrm{kg})\end{array}$} & \multirow{2}{*}{$\begin{array}{c}\text { Alkali index } \\
\text { (kg alkali/GJ) }\end{array}$} \\
\hline & $\mathrm{K}_{2} \mathrm{O}$ & $\mathrm{SiO}_{2}$ & $\mathrm{MgO}$ & $\mathrm{P}_{2} \mathrm{O}_{5}$ & $\mathrm{CaO}$ & $\mathrm{Fe}_{2} \mathrm{O}_{3}$ & $\mathrm{SO}_{3}$ & $\mathrm{Na}_{2} \mathrm{O}$ & $\mathrm{Cl}$ & & \\
\hline OMW & 31.90 & 27.75 & 18.43 & 6.83 & 5.52 & 1.64 & 1.10 & n.d. & 1.40 & 26.43 & 0.66 \\
\hline $\begin{array}{c}\text { OMW } \\
\left(225^{\circ} \mathrm{C}, 2 \mathrm{~h}\right)\end{array}$ & 28.11 & 2.83 & 2.47 & 4.76 & n.d. & 0.90 & 3.03 & n.d. & 0.72 & 29.63 & 0.21 \\
\hline $\begin{array}{c}\text { OMW } \\
\left(225^{\circ} \mathrm{C}, 4 \mathrm{~h}\right)\end{array}$ & 22.17 & 2.74 & 2.05 & 3.30 & n.d. & 0.39 & 3.05 & n.d. & 0.38 & 31.04 & 0.16 \\
\hline $\begin{array}{c}\text { OMW } \\
\left(225^{\circ} \mathrm{C}, 8 \mathrm{~h}\right)\end{array}$ & 17.48 & 5.97 & 3.22 & 13.15 & 0.24 & 0.97 & n.d. & n.d. & 0.08 & 31.57 & 0.11 \\
\hline $\begin{array}{c}\text { OMW } \\
\left(225^{\circ} \mathrm{C}, 24 \mathrm{~h}\right) \\
\end{array}$ & 11.81 & 3.66 & 3.52 & 15.88 & 7.83 & 1.54 & 4.70 & n.d. & n.d. & 33.21 & 0.08 \\
\hline $\begin{array}{c}\text { OMW } \\
\left(200^{\circ} \mathrm{C}, 2 \mathrm{~h}\right) \\
\end{array}$ & 32.82 & 4.52 & 0.99 & n.d. & n.d. & 0.67 & 1.98 & n.d. & 1.43 & 27.45 & 0.40 \\
\hline $\begin{array}{c}\text { OMW } \\
\left(250^{\circ} \mathrm{C}, 2 \mathrm{~h}\right)\end{array}$ & 12.59 & 3.01 & 3.47 & 10.56 & n.d. & 1.25 & 2.39 & n.d. & 0.14 & 32.50 & 0.07 \\
\hline CAW & 25.64 & n.d. & 3.52 & n.d. & n.d. & n.d. & 1.35 & 2.62 & 4.08 & 16.80 & 1.09 \\
\hline $\begin{array}{c}\mathrm{CAW} \\
\left(200^{\circ} \mathrm{C}, 2 \mathrm{~h}\right)\end{array}$ & 23.95 & n.d. & 3.20 & n.d. & n.d. & n.d. & 1.42 & 4.44 & 5.21 & 25.09 & 0.80 \\
\hline $\begin{array}{c}\text { CAW } \\
\left(225^{\circ} \mathrm{C}, 2 \mathrm{~h}\right)\end{array}$ & 25.70 & n.d. & 2.42 & n.d. & n.d. & n.d. & 1.56 & 1.99 & 4.02 & 26.17 & 0.74 \\
\hline $\begin{array}{c}\mathrm{CAW} \\
\left(250^{\circ} \mathrm{C}, 2 \mathrm{~h}\right) \\
\end{array}$ & 20.73 & n.d. & 3.54 & n.d. & n.d. & n.d. & 2.01 & n.d. & 6.46 & 30.26 & 0.50 \\
\hline OJW & 28.99 & n.d. & 2.46 & n.d. & n.d. & 0.13 & 2.70 & n.d. & 1.16 & 18.21 & 0.53 \\
\hline $\begin{array}{c}\text { OJW } \\
\left(200^{\circ} \mathrm{C}, 2 \mathrm{~h}\right)\end{array}$ & 8.08 & n.d. & 0.87 & n.d. & n.d. & n.d. & 1.13 & n.d. & 0.10 & 26.78 & 0.12 \\
\hline $\begin{array}{c}\text { OJW } \\
\left(225^{\circ} \mathrm{C}, 2 \mathrm{~h}\right)\end{array}$ & 16.21 & n.d. & 3.06 & n.d. & n.d. & n.d. & 2.67 & n.d. & 0.44 & 27.73 & 0.26 \\
\hline $\begin{array}{c}\text { OJW } \\
\left(250^{\circ} \mathrm{C}, 2 \mathrm{~h}\right)\end{array}$ & 12.08 & n.d. & 4.10 & 0.41 & n.d. & n.d. & 4.19 & n.d. & 0.26 & 30.35 & 0.16 \\
\hline
\end{tabular}

Table 3. Energy estimation to evaluate the TF and HTC processes in terms of the thermal treatments applied to the water contained in the wastes.

\begin{tabular}{|c|c|c|c|c|c|c|c|c|}
\hline $\begin{array}{l}\text { Type of } \\
\text { waste }\end{array}$ & $\begin{array}{c}\mathrm{E}_{\mathrm{TF}} \\
(\mathrm{kJ} / \mathrm{kg} \\
\text { waste) }\end{array}$ & $\begin{array}{l}\text { Time } \\
\text { (h) }\end{array}$ & $\begin{array}{l}\mathrm{T}_{\text {HTC }} \\
\left({ }^{\circ} \mathrm{C}\right)\end{array}$ & $\begin{array}{c}\mathrm{H}_{2} \\
(\mathrm{~kJ} / \mathrm{kg} \\
\text { water) }\end{array}$ & $\begin{array}{c}\text { Energy } 2 \\
\text { (kJ/kg } \\
\text { waste) }\end{array}$ & $\begin{array}{c}\text { Energy } 3 \\
\text { (kJ/kg } \\
\text { waste) }\end{array}$ & $\begin{array}{c}E_{\text {HTC }} \\
(\mathrm{kJ} / \mathrm{kg} \\
\text { waste) }\end{array}$ & $\begin{array}{c}\text { Energy } \\
\text { Saving } \\
(\%)\end{array}$ \\
\hline \multirow{6}{*}{ OMW } & \multirow{6}{*}{1821} & 2 & 225 & 971 & 627 & 554 & 1181 & 35.1 \\
\hline & & 4 & 225 & 971 & 627 & 465 & 1093 & 40.0 \\
\hline & & 8 & 225 & 971 & 627 & 330 & 958 & 47.4 \\
\hline & & 24 & 225 & 971 & 627 & 150 & 777 & 57.3 \\
\hline & & 2 & 200 & 855 & 545 & 698 & 1243 & 31.7 \\
\hline & & 2 & 250 & 1092 & 713 & 126 & 839 & 53.9 \\
\hline \multirow{3}{*}{ CAW } & \multirow{3}{*}{2213} & 2 & 200 & 855 & 663 & 1029 & 1692 & 23.5 \\
\hline & & 2 & 225 & 971 & 763 & 935 & 1698 & 23.3 \\
\hline & & 2 & 250 & 1092 & 867 & 438 & 1305 & 41.0 \\
\hline \multirow{3}{*}{ OJW } & \multirow{3}{*}{2045} & 2 & 200 & 855 & 612 & 1131 & 1744 & 13.04 \\
\hline & & 2 & 225 & 971 & 705 & 994 & 1698 & 13.05 \\
\hline & & 2 & 250 & 1092 & 801 & 655 & 1456 & 28.8 \\
\hline
\end{tabular}





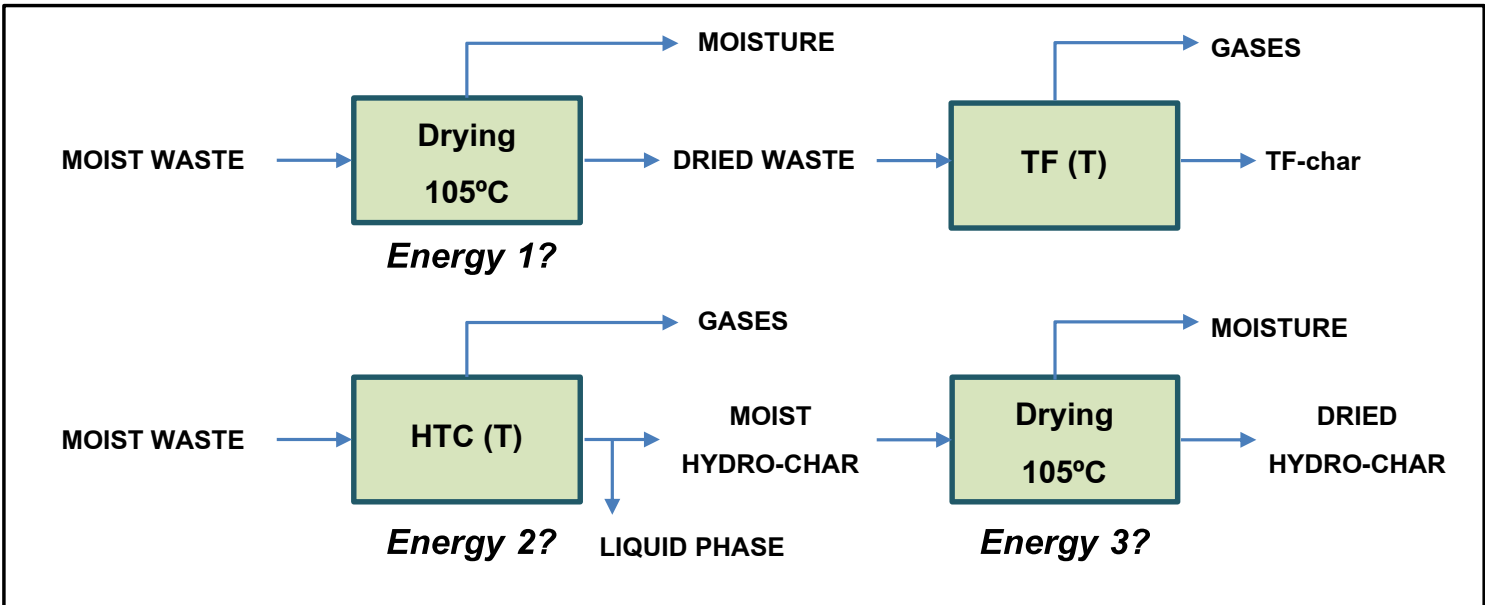

4

Fig. 1. TF and HTC schemes to compare the energy requirements in terms of the 6 thermal treatment of the water contained in wastes. 
(a)

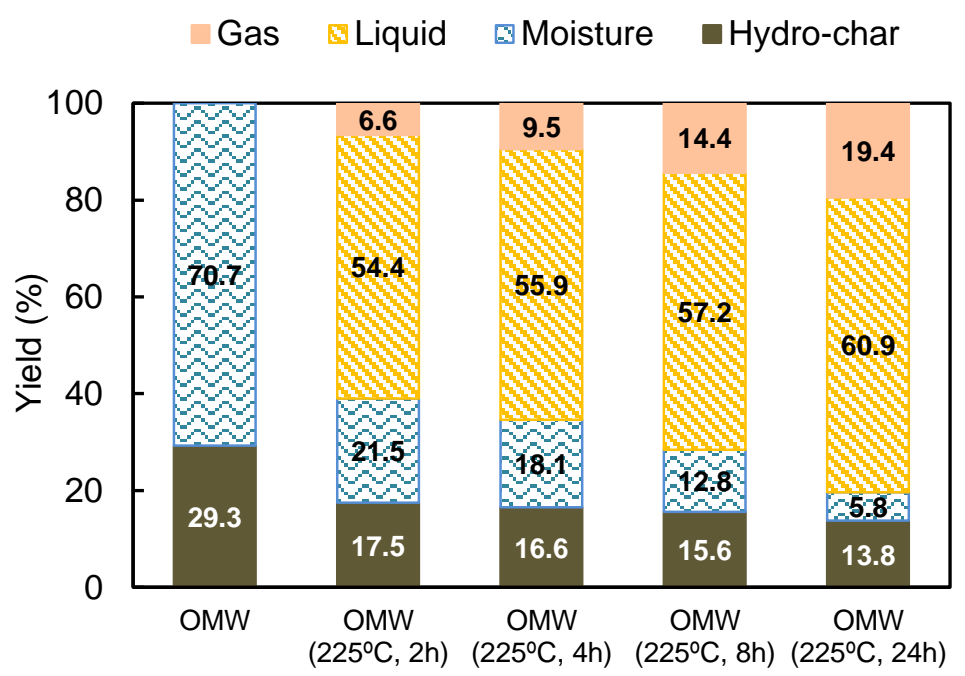

3

(b)

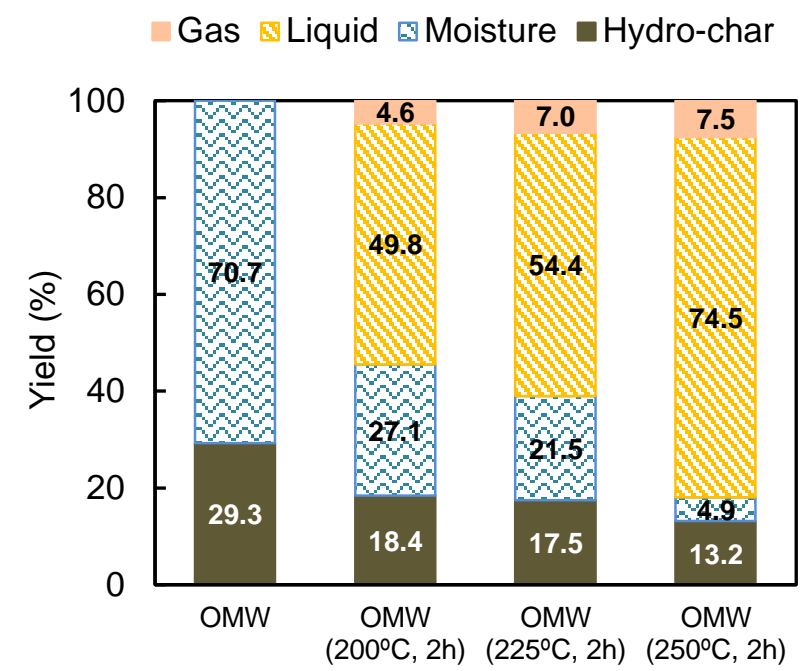

5

c)

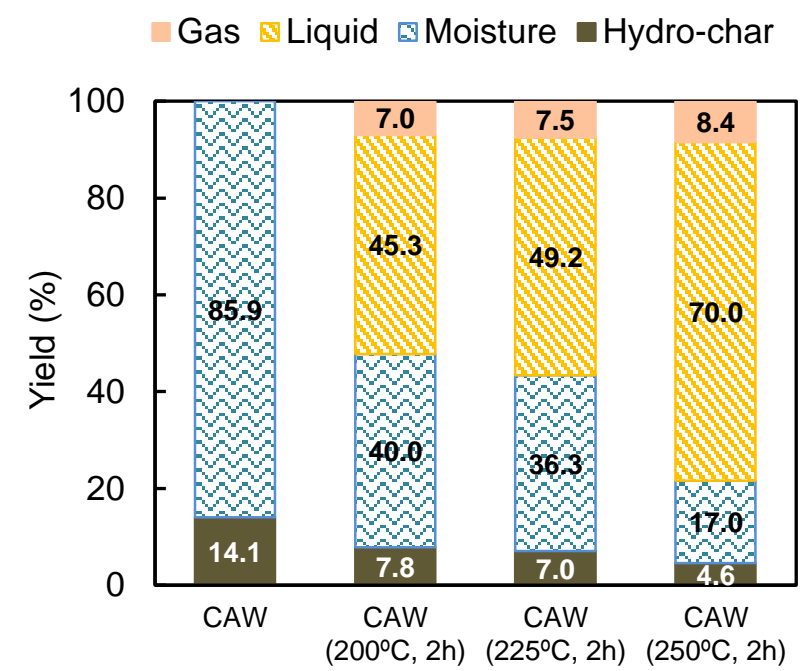


d)

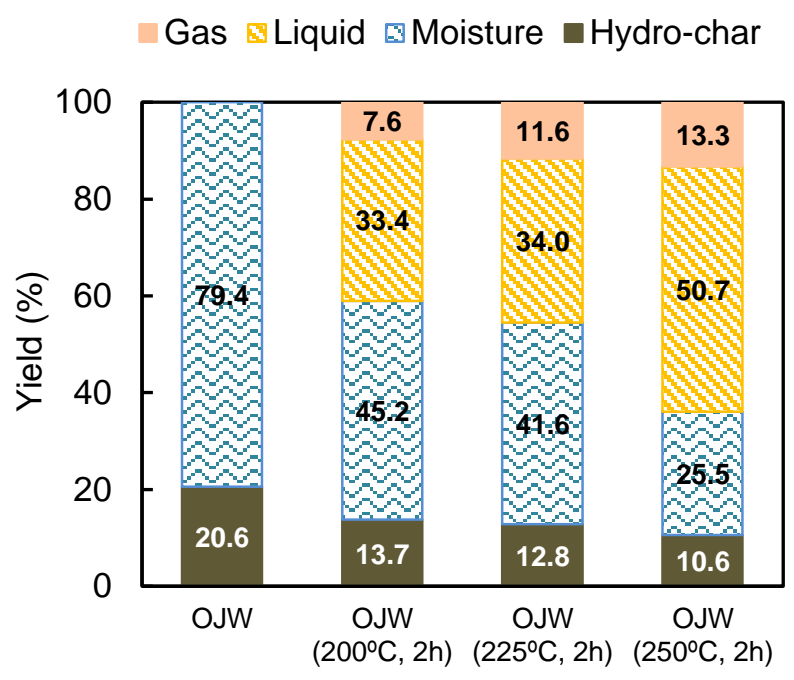

9

10 Fig. 2. Reaction product yields (w.t.\%) of wastes and hydro-chars from (a) OMW at $11225^{\circ} \mathrm{C}$ and different residence times. (b) OMW at different temperatures during $2 \mathrm{~h}$. (c) $12 \mathrm{CAW}$ at different temperatures during $2 \mathrm{~h}$. (d) OJW at different temperatures during $2 \mathrm{~h}$. 13

14 15 16 17 18 19 


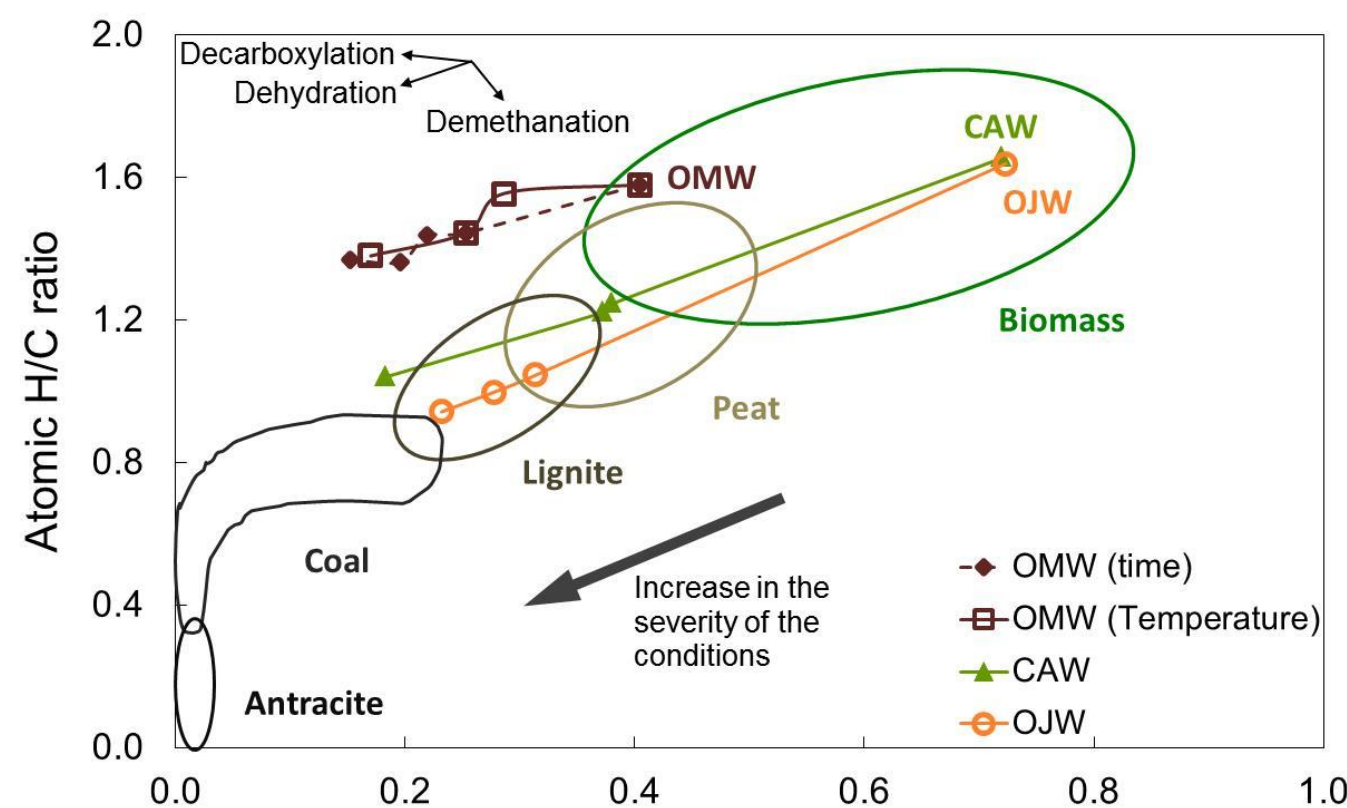

3

Atomic O/C ratio

4

5 Fig. 3. Van Krevelen diagram for the solid fuel production from OMW, CAW and OJW 6 through hydrothermal carbonization.

7

8

9 


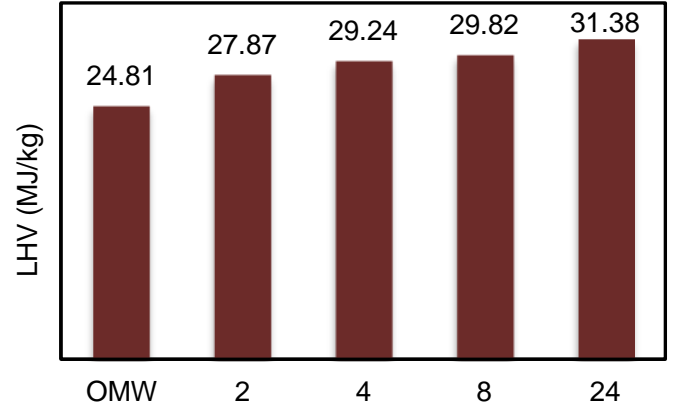

Time (h)

(a)

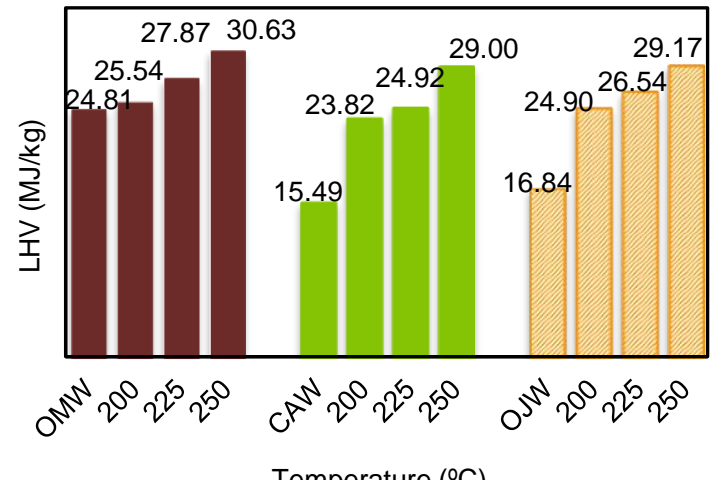

Temperature $\left({ }^{\circ} \mathrm{C}\right)$

(b)

5

6 Fig. 4. Low heating value $\left(\mathrm{MJ} / \mathrm{kg}\right.$ ) of the hydro-chars obtained (a) from OMW at $225^{\circ} \mathrm{C}$ 7 and different residence times. (b) OMW, CAW and OJW at different temperatures 8 during $2 \mathrm{~h}$.

9

10 


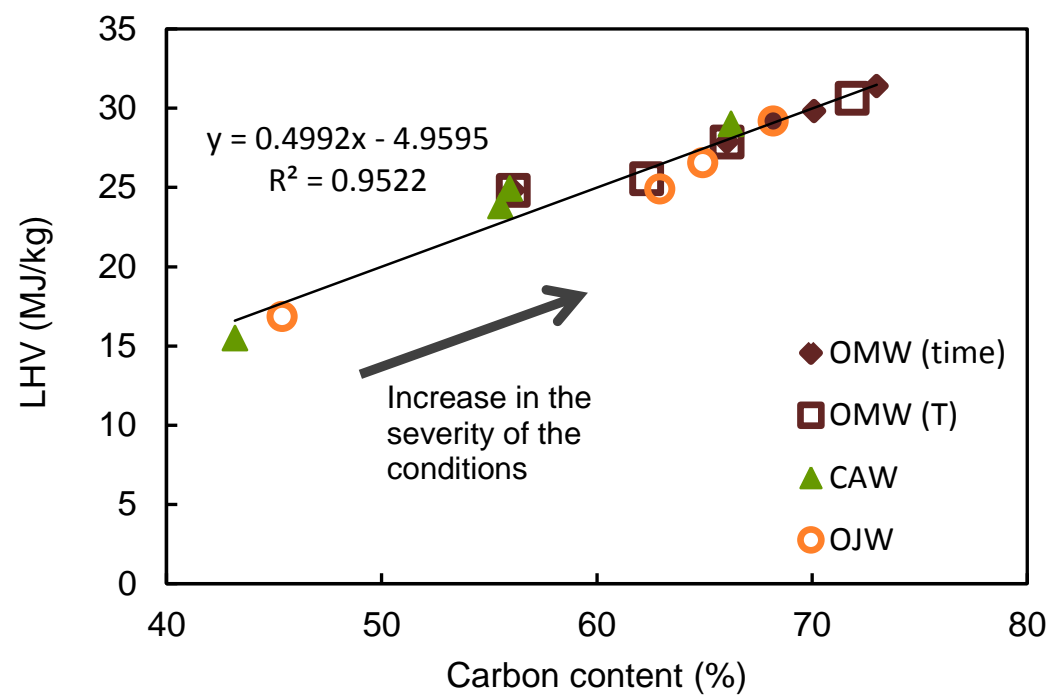

4

5

6 Fig. 5. Low heating value and carbon content diagram representing the hydro-chars

7 obtained from OMW, CAW and OJW under different experimental conditions

8

(OMW(time): $225^{\circ} \mathrm{C}$ during 2, 4, 8 and 24 hours; OMW (T), CAW and OJW: 200, 225

9 and $250^{\circ} \mathrm{C}$ during 2 hours).

10

11

12 


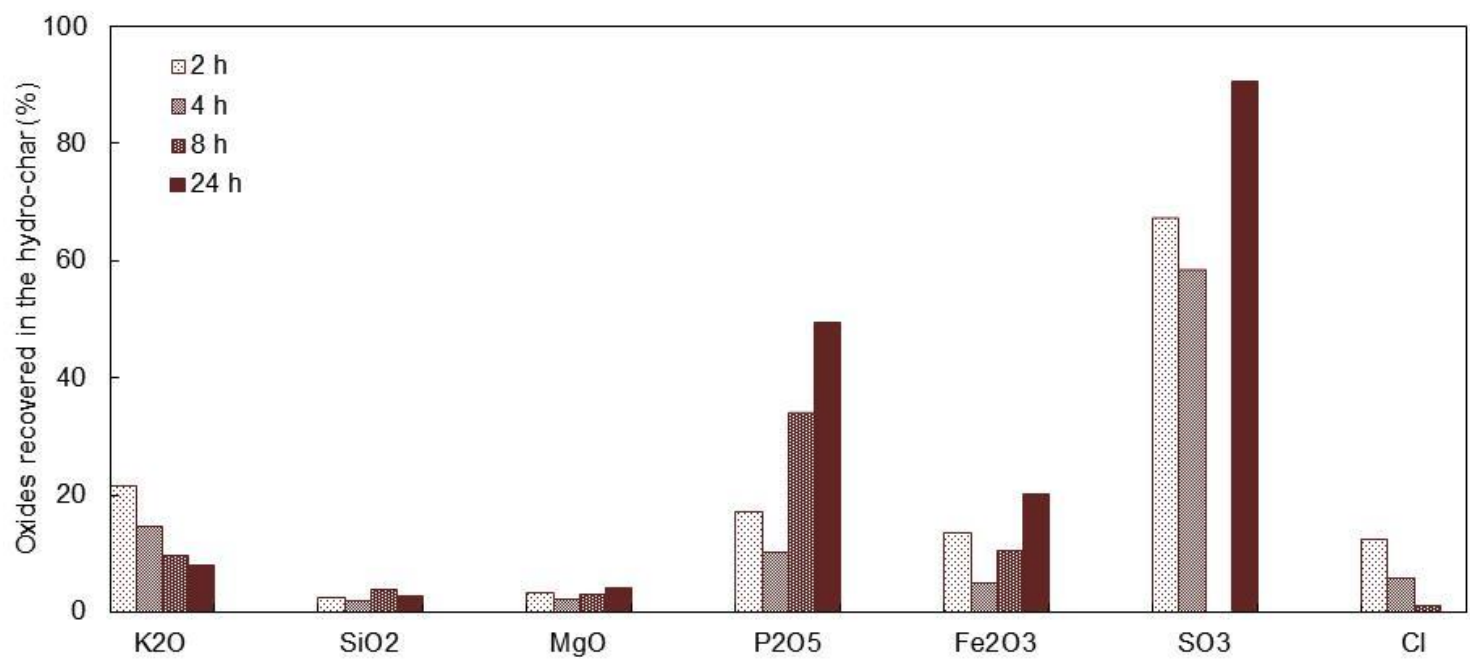

2

(a)

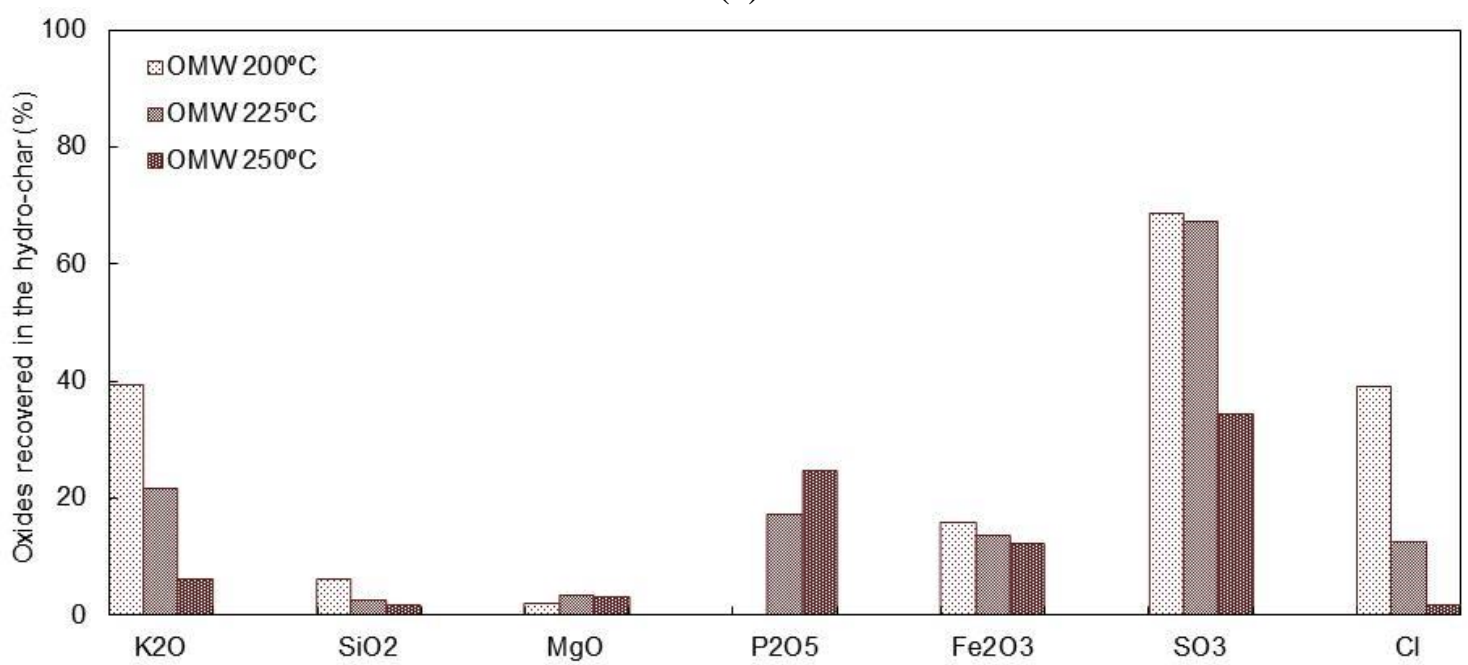

3

(b)

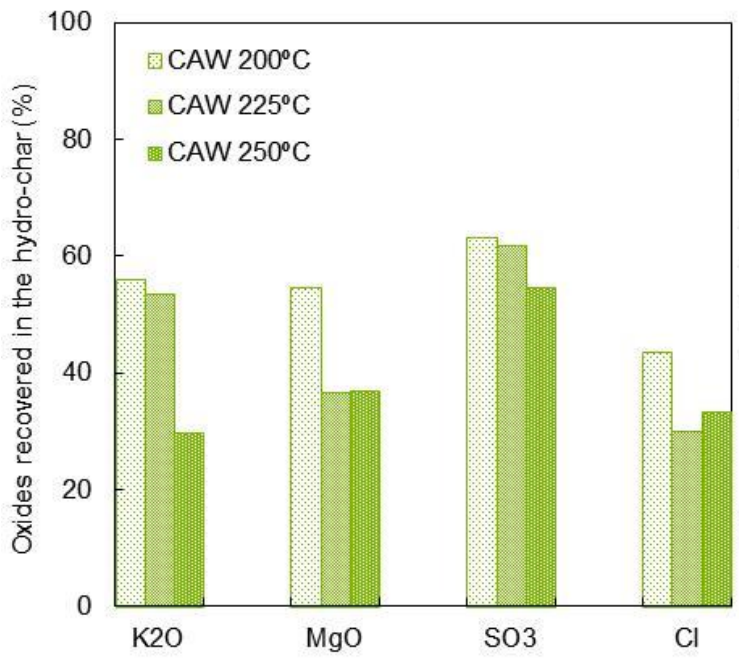

(c)

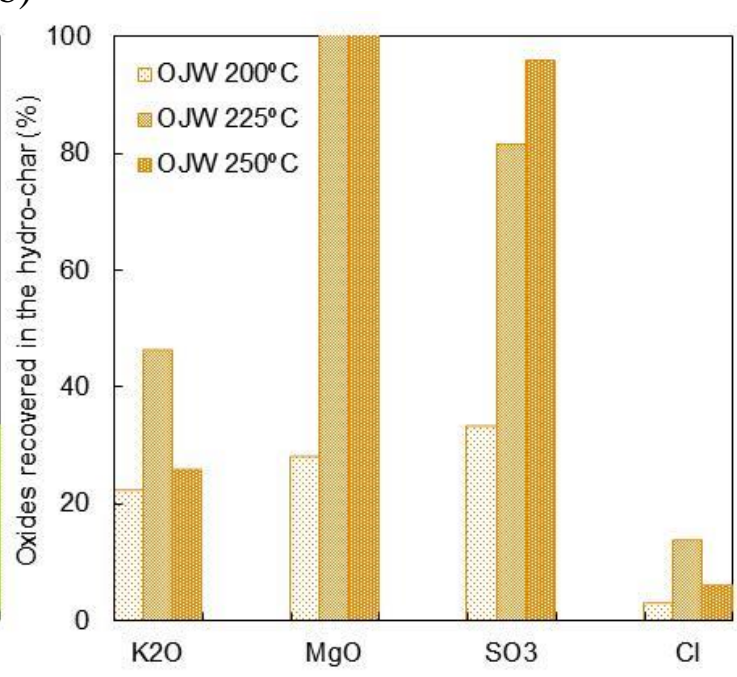

(d)

8 Fig. 6. Percentage of oxides retained by the hydro-chars obtained from (a) OMW at $225^{\circ} \mathrm{C}$ and different residence times. (b) OMW, (c) CAW and (d) OJW at different temperatures during $2 \mathrm{~h}$. 